\title{
Antinuclear antibody-positive ticlopidine-induced hepatitis
}

\author{
SANDER JO VELDHUYZEN VAN ZANTEN MD PhD, C WILliam MCCORMICK MD
}

\begin{abstract}
SJO Veldhuyzen van Zanten, CW McCormick. Anti-nuclear antibody-positive ticlopidine-induced hepatitis. Can J Gastroenterol 1996;10(4):231-232. Ticlopidine hydrochloride has been shown to reduce the risk of first or recurrent stroke in patients who have experienced a transient ischemic attack, reversible ischemic neurological deficit, recurrent stroke or first stroke. Severe liver dysfunction is a contraindication for its use. Increase in liver enzymes has been reported with use of this drug, but jaundice is rare. A case of severe ticlopidine-induced hepatitis that was associated with a marked increase in antinuclear antibody (ANA) levels is reported. Physicians prescribing ticlopidine hydrochloride should be aware that a potentially severe acute hepatitis associated with ANA positivity can occur. The drug should be discontinued if signs of liver dysfunction occur.
\end{abstract}

Key Words: Adverse effect, Antinuclear antibody, Hepatitis, Ticlopidine

\section{Hépatite positive à l'égard des anticorps antinucléaires induite par la ticlopidine}

RÉSUMÉ : Le chlorhydrate de ticlopidine s'est révélé apte à réduire le risque d'AVC de novo ou récurrent chez les patients qui ont souffert d'un accès ischémique transitoire, d'un déficit neurologique ischémique réversible, d'ACV récurrents ou de premier $\mathrm{ACV}$. Une grave dysfonction hépatique est une contre-indication à son emploi. L'emploi de ce médicament a été associé à une augmentation des enzymes hépatiques, mais la jaunisse est rare. Nous signalons ici le cas d'une grave hépatite induite par la ticlopidine qui a été associée à une augmentation marquée des taux d'anticorps antinucléaires (AAN). Les médecins qui prescrivent du chlorhydrate de ticlopidine devraient être au courant du risque d'hépatite grave aiguë associée à un statut positif à l'égard de l'AAN. Le médicament doit être cessé dès les premiers signes de dysfonction hépatique.
$\mathrm{T}$ iclopidine hydrochloride has been shown to reduce the risk of first or recurrent stroke in patients who have experienced a transient ischemic attack, reversible ischemic neurological deficit, recurrent stroke or first stroke $(1,2)$. Severe liver dysfunction is a contraindication for its use. Increase in liver enzymes has been reported with use of this drug, but jaundice is rare (3).

We report a case of severe ticlopidine-induced hepatitis that was associated with a marked increase in antinuclear antibody (ANA) levels.

\section{CASE PRESENTATION}

A 62-year-old Caucasian male suffered a stroke that was associated with right-sided paralysis. There was a history of two transient ischemic attacks during the previous year, and for this he was taking acetylsalicylic acid $325 \mathrm{mg}$ daily; later dipyridamole $50 \mathrm{mg}$ tid was added. He recovered from his stroke without any significant residual neurological deficits.
There was no history of liver disease and he had never received a blood transfusion. Family history for liver disease was negative. He only consumed alcohol on rare occasions. The only other medication he had been taking was alprazolam $0.25 \mathrm{mg} /$ day.

He was started on ticlopidine $250 \mathrm{mg}$ tid to prevent recurrent strokes. On day 35 he started to feel generally unwell, developed nausea and loss of appetite. He noticed that his urine became dark. Ticlopidine was stopped on day 38. On physical examination he was markedly jaundiced. No stigmata of chronic liver disease were present apart from $\mathrm{Du}$ puytren's contractures in both hands. There was no asterixis. The liver edge was just palpable below the costal margin and slightly tender. The rest of the physical examination was unremarkable except for slight loss of power in the right arm and leg.

Results of blood work are shown in Table 1. ANA showed

Division of Gastroenterology and Division of Neurology, Department of Medicine, Dalhousie University, Halifax, Nova Scotia

Correspondence: Dr Veldhuyzen van Zanten, Division of Gastroenterology, Victoria General Hospital, RC Dickson Centre, Room 4087,

1278 Tower Road, Halifax, Nova Scotia B3H 2Y9. Telephone 902-428-2397, fax 902-428-2558, e-mail zanten@is.dal.ca

Received for publication June 21, 1995. Accepted October 4, 1995 
TABLE 1

\section{Results of blood work}

\begin{tabular}{|c|c|c|c|c|c|c|c|}
\hline & \multicolumn{7}{|c|}{ Day } \\
\hline & 0 & 35 & 38 & 44 & 60 & 78 & 118 \\
\hline AST $(n<31$ U/L) & 25 & 206 & 217 & 96 & 27 & 29 & 13 \\
\hline ALT $(n<42 \mathrm{U} / \mathrm{L})$ & 29 & 497 & 511 & 283 & 44 & 34 & 16 \\
\hline ALP $(n<104$ U/L) & 102 & 521 & 651 & 696 & 179 & 148 & 69 \\
\hline $\mathrm{GT}(\mathrm{n}<40 \mathrm{U} / \mathrm{L})$ & 29 & - & 1119 & 838 & 322 & 105 & 59 \\
\hline Bili total $(\mathrm{n}<16 \mathrm{~mol} / \mathrm{L})$ & 14 & 123 & 128 & 50 & 22 & 10 & 10 \\
\hline Bili direct $(\mathrm{n}<10 \mathrm{~mol} / \mathrm{L})$ & 2 & 61 & 68 & - & 4 & - & - \\
\hline ANA titre & - & - & $>1: 1600$ & $1: 400$ & - & $1: 100$ & - \\
\hline
\end{tabular}

ALP Alkaline phosphatase; ALT Alanine aminotransferase; ANA Antinuclear antibody; AST Aspartate aminotransferase; Bili Bilirubin; $\gamma$ GT Gamma glutamyl transferase

a homogeneous pattern. Complete blood count, erythrocyte sedimentation rate, total eosinophil count, prothrombin time, partial thromboplastin time, total protein and albumin were normal. Hepatitis A serology was immunoglobulin (Ig) G-positive and IgM-negative. Hepatitis B and C serology and monospot were negative. Hepatitis $\mathrm{C}$ serology repeated after 18 months was still negative. Abdominal ultrasound of the liver, biliary tree and pancreas was normal. A liver biopsy was not performed.

Without specific treatment the patient recovered completely. Jaundice resolved, liver enzymes returned to normal and the ANA became negative over the following 12 weeks. All liver blood work remained normal over the following 18 months.

\section{DISCUSSION}

We believe that this patient suffered from ticlopidineinduced acute hepatitis and that it was associated with transient ANA positivity. We believe that this is the first reported case of ticlopidine-associated ANA-positive acute hepatitis because a recent MEDLINE search retrieved no other such cases. The patient's hepatitis was severe but reversible after the medication was discontinued. He had no risk factors for viral hepatitis. Hepatitis $\mathrm{C}$ serology, repeated after 18 months and still negative, was done to rule out the possibility that the patient had an acute hepatitis $\mathrm{C}$ infection and had not yet developed antibodies.

Alprazolam as a cause of ticlopidine-associated ANApositive acute hepatitis seems unlikely because the patient had been taking this medication for a long time. However,

\section{REFERENCES}

1. Gent M, Blakely JA, Easton JD, et al. The Canadian American Ticlopidine Study (CATS) in thromboembolic stroke. Lancet 1989:i:1215-20.

2. Hass WK, Easton JD, Adams HP, et al. A randomized trial comparing ticlopidine hydrochloride with aspirin for the prevention of stroke in high risk patients. N Engl J Med 1989;321:501-7.

3. Ticlopidine Hydrochloride (Product Monograph). Mississauga: Hoffmann-La Roche Limited, 1991.

4. Nurhussen MA. Ticlopidine-induced prolonged cholestasis. J Am Geriatr Soc 1993;41:1371-2. he has not been rechallenged with alprazolam. We are unaware of any reports of alprazolam-induced hepatitis. We recently became aware of another case of acute hepatitis in a 73 -year-old woman that occurred four weeks after ticlopidine $250 \mathrm{mg}$ tid was started. Maximum enzyme levels were alanine aminotransferase $728 \mathrm{U} / \mathrm{L}$, aspartate aminotransferase (AST) $348 \mathrm{U} / \mathrm{L}$, alkaline phosphatase $448 \mathrm{U} / \mathrm{L}$ and total bilirubin $52 \mathrm{U} / \mathrm{L}$, but ANA was not determined. Liver enzyme abnormalities completely resolved by three weeks after ticlopidine discontinuation.

Most patients treated with ticlopidine hydrochloride show some increase above baseline in their levels of alkaline phosphatase, and the increase exceeded the upper range of normal in approximately one-third of patients (3). In $6 \%$ of patients, the value was more than twice the upper reference limit (3). The maximum rise, which is generally asymptomatic, occurs at one to four months of therapy and is not progressive. Elevations in AST and bilirubin occur occasionally. In two patients $(0.1 \%$ of total patients) who participated in clinical trials, cholestatic jaundice associated with elevations of serum aminotransferase levels occurred. The jaundice disappeared after ticlopidine was discontinued (3). Two cases of prolonged (12 to 15 weeks), severe cholestasis have been reported in a 91 - and a 92-year-old $(4,5)$. In an animal model of isolated perfused rat liver, repeated administration of ticlopidine induced cholestasis (6). The Canadian Adverse Drug Reaction Newsletter reported 11 cases of jaundice over 26 months; one patient died of hepatorenal syndrome (7). In all the reports the mean onset of jaundice from the start of the drug was 33 days (range 10 to 57) (4).

High titres of ANA have been reported in association with other drug-induced hepatitis, eg, hydralazine, methyldopa, isoniazid and sulphonamides $(8,9)$. The mechanism of this phenomenon is unknown but likely immunological in origin.

\section{CONCLUSIONS}

Physicians prescribing ticlopidine hydrochloride should be aware that a potentially severe acute hepatitis associated with ANA positivity can occur. The drug should be discontinued if signs of liver dysfunction occur.

ACKNOWLEDGEMENTS: Dr Veldhuyzen van Zanten holds a Career Award from the Pharmaceutical Manufacturers Association of Canada/Medical Research Council.

5. Grimm IS, Litynski JJ. Severe cholestasis associated with ticlopidine. Am J Gastroenterol 1994;89:279-80.

6. Alvaro D, Gigliozzi A, Gaudio E, et al. Ticlopidine induced cholestasis: report of two cases and experimental evidence of the drug's adverse effect in isolated perfused rat liver. Eur J Gastroenterol Hepatol 1994;6:943-50.

7. Ticlopidine HCl-hematological and liver effects. Can Adverse Drug Reaction Newsl 1993;3:1-2.

8. Avery GS. Drug Treatment. Sydney: ADIS Press, 1976:175.

9. Forster HS. Hepatitis from hydralazine. N Engl J Med 1980;302:1362. 


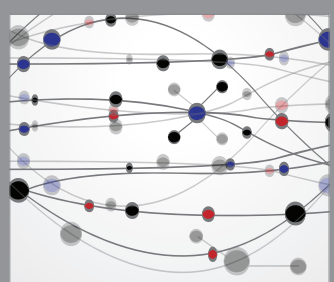

The Scientific World Journal
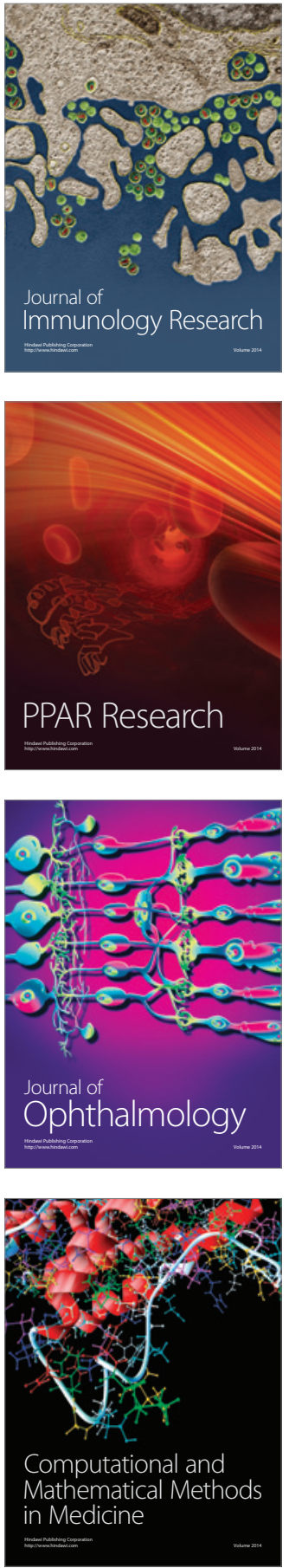

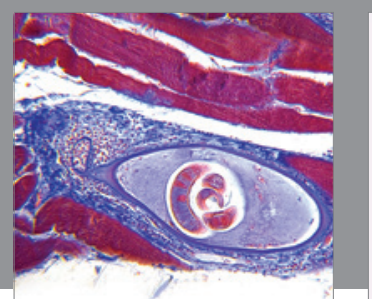

Gastroenterology Research and Practice

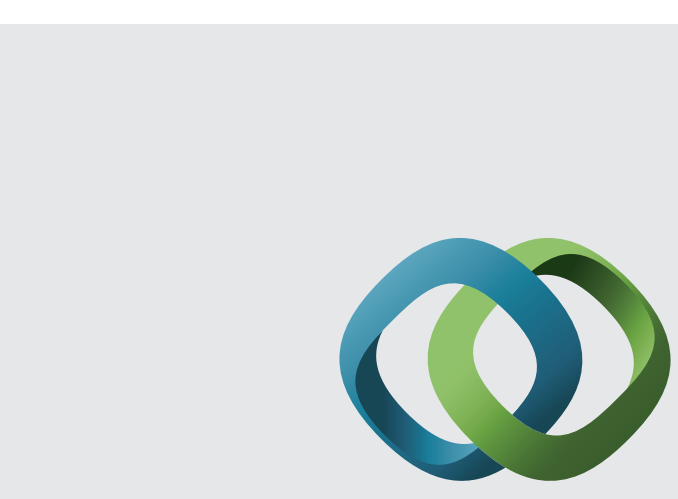

\section{Hindawi}

Submit your manuscripts at

http://www.hindawi.com
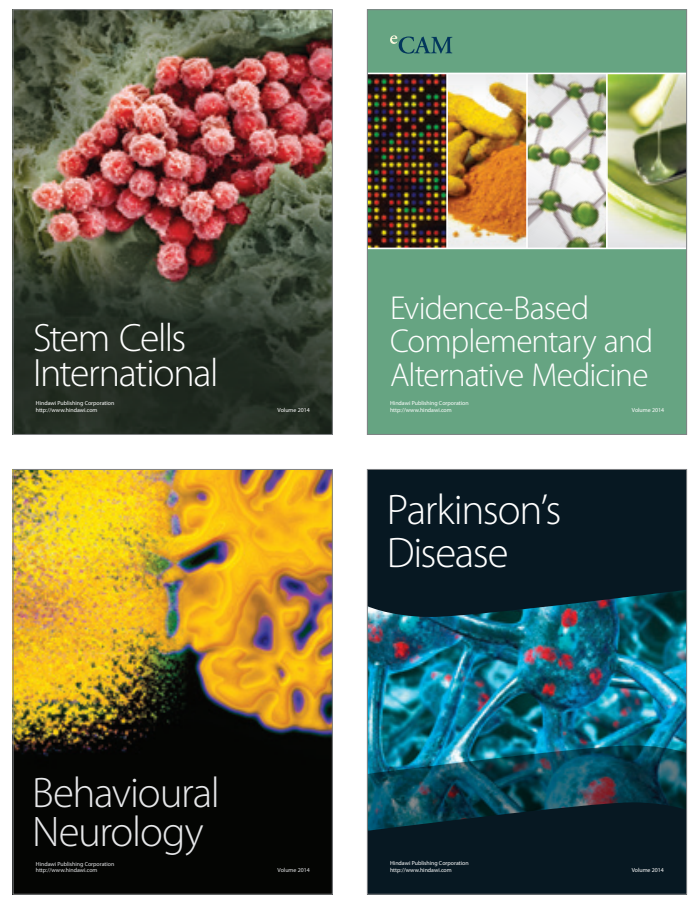
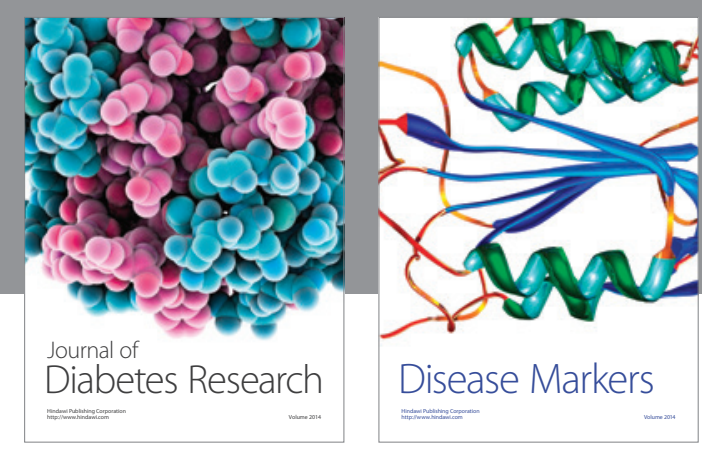

Disease Markers
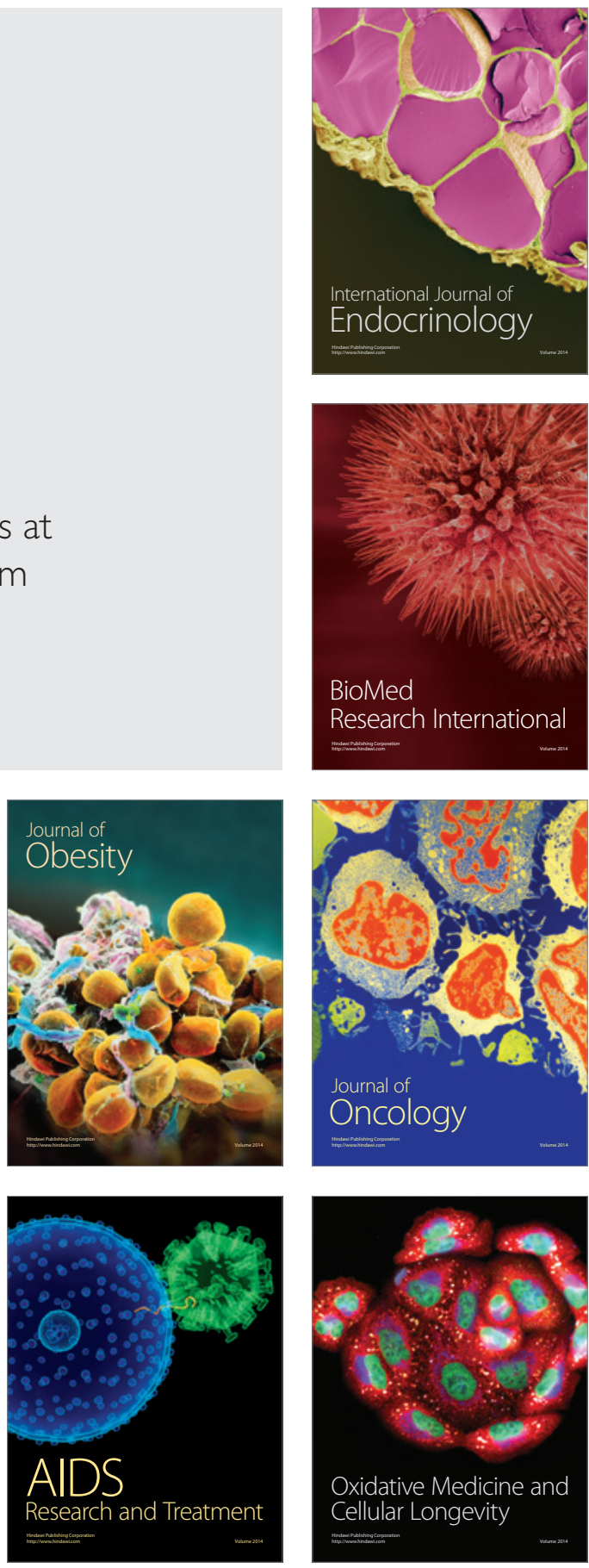